\title{
Real-time continuous glucose monitoring (CGM) integrated into the treatment of type 1 diabetes: Consensus of experts from SFD, EVADIAC and SFE
}

P.-Y. Benhamou ${ }^{a}$, B. Catargi ${ }^{b}$, B. Delenne ${ }^{c}$, B. Guerci ${ }^{d}$, H. Hanaire, , N. Jeandidier ${ }^{f}$, R. Leroyg, L. Meyer ${ }^{h}$, A. Penfornis ${ }^{i}$, R.-P. Radermecker ${ }^{j}$, E. Renard ${ }^{k}$, S. Baillot-Rudonil, J.-P. Riveline ${ }^{m}$, P. Schaepelynck ${ }^{n}$, A. Sola-Gazagnes ${ }^{o}$, V. Sulmont ${ }^{p}$, N. Tubiana-Rufi ${ }^{q}$, D. Durain ${ }^{r}$, I. Mantovani $^{s}$ Coordination: A. Sola-Gazagnes ${ }^{o}$, J.-P. Riveline ${ }^{m}$

Société Francophone du Diabète (SFD), Société Française d'Endocrinologie (SFE) and EVADIAC group (EVAluation dans le Diabète des Implants ACtifs)

${ }^{a}$ Service Endocrinologie-Diabétologie-Nutrition, CHU Grenoble, et Université Grenoble-1, France

${ }^{b}$ Service Endocrinologie-Diabétologie, CHU Bordeaux, France

${ }^{c}$ Service Endocrinologie-Diabétologie, CHG Aix, France

${ }^{d}$ Université de Nancy I et Service de diabétologie, maladies métaboliques et maladies de la nutrition, CHU de Nancy, Hôpitaux de Brabois, France

${ }^{e}$ Service de Diabétologie, Maladies Métaboliques, Nutrition, CHU de Toulouse, France

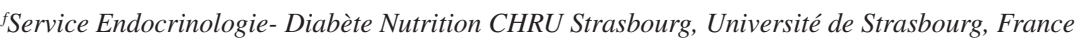

${ }^{8}$ Endocrinologue libéral, Lille, France

${ }^{h}$ Endocrinologue libéral, Strasbourg, France

¿Service d'Endocrinologie-Métabolisme et Diabétologie-Nutrition, CHU Besançon, EA3920, Université de Franche-Comté, boulevard Fleming, 25030 Besançon cedex, France

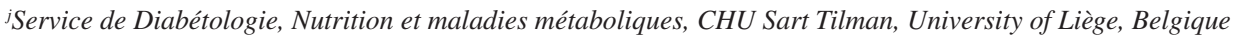

${ }^{k}$ Département d'Endocrinologie, Diabète, Nutrition, CHU de Montpellier et Université Montpellier I, France

'Service Endocrinologie-Diabétologie, CHU Dijon, France

${ }^{m}$ Service de Diabétologie et Endocrinologie, Centre Hospitalier Sud-Francilien; Université Pierre et Marie Curie-Paris 6, UMR-S 872, France

${ }^{n}$ Service de Nutrition-Endocrinologie-Maladies Métaboliques, CHU Marseille, Hôpital Sainte Marguerite, France

${ }^{\circ}$ Service Endocrinologie-Diabétologie, CHU Hôtel Dieu, APHP, Paris, France

${ }^{p}$ Service de pédiatrie A, CHU Reims American Memorial Hospital, CHU de Reims, France

${ }^{q}$ Service Endocrinologie-Diabétologie, Hôpital Robert Debré, APHP, Paris, France

${ }^{r}$ Service Endocrinologie-Diabétologie, Nancy, France

${ }^{s}$ Service Endocrinologie-Diabétologie, Monaco

\section{Summary of recommendations}

The use of CGM necessitates strong involvement on the part of the diabetic patient in the management of his treatment. The success of CGM depends on patient selection, training and follow-up:

- the effectiveness of CGM is significantly correlated to the length of time sensors are used. Nevertheless, the metabolic benefit of CGM doesn't necessarily require full-time use of the device. Forty percent use seems the minimum necessary. The optimal duration and frequency of use are not known and must be personalised;

- the profile of "responsive" patients who get the best outcome from CGM has yet to be determined. Frequency of prior daily self- monitoring of blood glucose (SMBG) seems to be a predictive factor;

- use of CGM in the first month is predictive of its subsequent use. A trial period generally of less than one month should be proposed to candidates. Evaluation at one month almost always makes it possible to tell whether or not the 
patient has adjusted to wearing the sensor, has accepted the constraints imposed by the technique and sees the benefits of its use;

- the patient requires two types of training, the first in the technique and the second in the interpretation and appropriate use of the data:

- a medical team skilled in the new technology and particularly in CGM is needed to conduct a specific educational program;

- a specifically trained nurse can handle the technical training;

- a re-evaluation of the benefit/cost/risk ratio of CGM must be done at 1 month (the trial period) and at 3 months to determine if CGM should be continued. After that, re-evaluation should be done at least once a year;

- suspension of the use of CGM on the advice of the physician or at the patient's request does not contraindicate a later attempt, after a certain delay, if the patient's motivation and medical situation justify it;

- the recommended indications for CGM are:

- a type 1 adult diabetic who - notwithstanding intensive treatment and management involving multiple injections or a pump, appropriate therapeutic education and SMBG several times a day, presents:

1. an $\mathrm{HbA}_{1 \mathrm{c}}$ over the target fixed by the French recommendations (www.has-sante.fr). Grade A;

2. and/or undetected or frequent mild hypoglycaemias, particularly nocturnal ones. Grade B;

3. and/or frequent severe hypoglycaemias. Professional agreement;

4. in the course of pregnancy or preparation for pregnancy, recommended $\mathrm{HbA}_{1 \mathrm{c}}$ target unattained or attained at the cost of mild frequent hypoglycaemias.

\section{Professional agreement;}

- children and adolescents with type 1 diabetes who, notwithstanding treatment and extensive management, have:

1. an $\mathrm{HbA}_{1 \mathrm{c}}$ over the target fixed by the recommendations (www.has-sante.fr). Grade B;

2. and/or undetected or frequent mild hypoglycaemias, particularly nocturnal ones. Grade B;

3. and/or severe hypoglycaemias. Professional agreement.

\section{Rationale for CGM}

The benefits of intensive treatment of type 1 diabetes have been well demonstrated in the DCCT [1]. This treatment is based on several elements: an insulin basal-bolus regimen administered by multiple injections or an insulin pump, self-monitoring of blood glucose (SMBG) including at least four measurements daily, specific education in the management of the treatment and therapeutic guidance in the adjustment of optimal insulin doses. During the study, patients implementing these measures achieved an average $\mathrm{HbA}_{1 \mathrm{c}}$ of $7.2 \%$, which helped prevent the onset or aggravation of microangiopathy [1] not only during the study but for more than 10 years afterwards [2]. These goals were achieved at the cost of an increase in severe hypoglycaemia [3] and did not alter the quality of life associated with diabetes [4]. Children and adolescents are a population with special needs, and adolescents participating in the DCCT [5], despite receiving the same treatments as adults, reached an average $\mathrm{HbA}_{1 \mathrm{c}} 1 \%$ higher, with 3 times as many severe hypoglycaemias.

In recent years, the use of insulin analogues, treatment with the insulin pump [6] and the development of educational methods [7] have reduced the risk of hypoglycaemia [8,9]. Nevertheless, therapeutic targets have yet to be achieved in practice. In the ENTRED 2007 study [10], only $26 \%$ of adult patients with type 1 diabetes reached an $\mathrm{HbA}_{1 \mathrm{c}}$ below $7 \%$ and $38 \%$ remained above $8 \%$. The incidence of hypoglycaemia is common in patients with less than $7 \% \mathrm{HbA}_{1 \mathrm{c}}[11]$ and increases with the duration of diabetes [12]. Frequent hypoglycaemias are associated with a decreased threshold of perception of hypoglycaemia, which increases the risk of severe hypoglycaemia and can reduce adherence to treatment [13].

Recently, devices allowing continuous glucose monitoring (CGM) in real time have been developed (Table 1). Their use with type 1 diabetes patients on a regimen of multiple injections or the pump makes possible a decrease in $\mathrm{HbA}_{1 \mathrm{c}}$ without an increase, and sometimes even with a decrease, in hypoglycaemia, depending on how often the device is employed [11].

Glucose sensors can be used in two ways: over a short period of time for purposes of diagnosis (henceforth called professional CGM or "glycaemic Holter"), or over the long term with real-time readouts (henceforth called personal CGM). Professional CGM has been routinely used in clinical practice over the past 10 years, for educational as well as diagnostic purposes. It makes it possible to explore a patient's ambulatory glucose profile under ordinary conditions of life. This tool is reliable, with the data available retrospectively (after download) or in real-time, depending on the indication. Interpretation of the data requires expertise and experience in the field. Nocturnal and postprandial glucose excursions not detected by SMBG have been identified as causes of failure of glucose control [14]. However, the contribution of professional CGM to improved glucose control in adult [15] and paediatric [16,51] populations is inconsistent $[17,18]$. The duration of a patient's use of CGM is apparently crucial to its effectiveness. Personal CGM, in the beginning, must be accompanied by specific training in the use of the data. This training must be done by an experienced team to optimise the use of the data [19]. The lack of such training and of patient selection will at the very least render CGM ineffective and at worst increase the risk of hypoglycaemia associated with excessive corrections [20]. CGM is effective in patients under an intensive insulin regimen, whether by pump or multiple injections [21]. No CGM device has proven to be superior to any other.

This consensus states the recommended indications for the use of personal CGM devices depending on their level of evidence and considers ways of implementing the technology 
Table 1

Devices allowing continuous glucose monitoring (CGM) in real time

\begin{tabular}{|c|c|c|c|c|c|}
\hline & Navigator & Dexcom Seven plus & Animas VIBE & \multicolumn{2}{|l|}{ Paradigm VEO } \\
\hline Technology & \multicolumn{5}{|c|}{ Subcutaneous sensor coated with the enzyme that measures interstitial glucose } \\
\hline $\begin{array}{l}\text { Start-Up } \\
\text { initialisation time }\end{array}$ & 1 hour most of the time & 2 hours & 2 hours & \multicolumn{2}{|l|}{3 hours } \\
\hline Calibrations & $\begin{array}{l}<1 / \text { day/calibrate at } 1 \mathrm{~h}, \\
2 \mathrm{~h}, 10 \mathrm{~h}, 24 \mathrm{~h}, 72 \mathrm{~h} \text { after } \\
\text { insertion }\end{array}$ & 2/day & 2/day & \multicolumn{2}{|c|}{$\begin{array}{l}\text { 2/day (every } 12 \text { hours; more during } \\
\text { initialisation if signal is unstable: Isig) }\end{array}$} \\
\hline Sensor life & 5 days & $\begin{array}{l}\text { Dexcom G3 sensor } \\
7 \text { days }\end{array}$ & $\begin{array}{l}\text { Dexcom G4 sensor } \\
7 \text { days }\end{array}$ & \multicolumn{2}{|l|}{6 days } \\
\hline $\begin{array}{l}\text { Displays } \\
\text { estimated glucose } \\
\text { numbers }\end{array}$ & Every minute & Every 5 minutes & Every 5 minutes & \multicolumn{2}{|c|}{ Every 5 minutes } \\
\hline $\begin{array}{l}\text { Transmitter/ } \\
\text { receiver range } \\
\text { (meter) }\end{array}$ & $3 \mathrm{~m}$ & $1.5 \mathrm{~m}$ & $3.6 \mathrm{~m}$ & \multicolumn{2}{|c|}{$\begin{array}{l}2 \mathrm{~m} / \text { diminution of the range of the signal } \\
\text { when patient sleeps in a position that } \\
\text { "muffles" the transmitter }\end{array}$} \\
\hline Age & 6 and over (version 1.5) & $\begin{array}{l}18 \text { and over (except } \\
\text { pregnant women and } \\
\text { persons on dialysis) }\end{array}$ & $\begin{array}{l}18 \text { and over (except } \\
\text { pregnant women and } \\
\text { persons on dialysis) }\end{array}$ & \multicolumn{2}{|l|}{7 and over } \\
\hline $\begin{array}{l}\text { Conditions of use } \\
\text { and restrictions }\end{array}$ & $\begin{array}{l}\text { Waterproof } \\
\text { (sensor and transmitter): } \\
\text { up to } 1 \text { meter for } \\
30 \mathrm{mn} / \text { electromagnetic } \\
\text { interferences (MRI, X-ray } \\
\text { and tonometer) }\end{array}$ & $\begin{array}{l}\text { Protection against } \\
\text { water splash } \\
\text { IPX5 (sensor } \\
\& \text { transmitter). } \\
\text { Waterproof up } \\
\text { to } 2.4 \text { meter for } \\
\text { 24h (IPX8)/ } \\
\text { electromagnetic } \\
\text { interferences (MRI) }\end{array}$ & $\begin{array}{l}\text { Protection against water } \\
\text { splash IPX5 (sensor\& } \\
\text { transmitter). Waterproof } \\
\text { up to } 2.4 \text { meter for } 24 \mathrm{~h} \\
\text { (IPX8)/electromagnetic } \\
\text { interferences (MRI)) }\end{array}$ & \multicolumn{2}{|c|}{$\begin{array}{l}\text { Waterproof (sensor and transmitter): } \\
\text { up to } 1.5 \text { meter for } 30 \text { min/electromagnetic } \\
\text { interferences (MRI, X-ray et tonometer) }\end{array}$} \\
\hline Displays & Yes & Yes & \multirow{2}{*}{$\begin{array}{l}\text { Yes } \\
1,3,6,12 \text { and } 24 \mathrm{~h} \\
\text { graphs }\end{array}$} & \multirow{2}{*}{\multicolumn{2}{|c|}{$\begin{array}{l}\text { Yes } \\
3,6,12 \text { and } 24 \mathrm{~h} \\
\text { graphs }\end{array}$}} \\
\hline $\begin{array}{l}\text { Directional } \\
\text { Trends }\end{array}$ & $\begin{array}{l}2,4,6,12 \text { and } 24 \mathrm{~h} \\
\text { graphs }\end{array}$ & $\begin{array}{l}1,3,6,12 \text { and } 24 \mathrm{~h} \\
\text { graphs }\end{array}$ & & & \\
\hline $\begin{array}{l}\text { Predictive alarms } \\
\text { for low/high } \\
\text { Alarms for rate } \\
\text { of change }\end{array}$ & $\begin{array}{l}\text { Yes, can be set to warn } \\
10,20,30 \mathrm{mn} \text { before } \\
\text { glucose limit has been } \\
\text { reached (setting in several } \\
\text { steps }-8 \text { sorts of alarms } \\
\text { available) }\end{array}$ & $\begin{array}{l}\text { Alarms for rate of } \\
\text { change in each high } \\
\text { and low }\end{array}$ & $\begin{array}{l}\text { Alarms for rate of change } \\
\text { in each high and low }\end{array}$ & $\begin{array}{l}5,10,15,20,2 \\
\text { limit has been }\end{array}$ & $\begin{array}{l}30 \mathrm{mn} \text { before glucose } \\
\text { ached }\end{array}$ \\
\hline $\begin{array}{l}\text { Sites of insertion } \\
\text { (Sensor Canula } \\
\text { size) }\end{array}$ & $\begin{array}{l}\text { Arm (back) and abdomen } \\
(5 \mathrm{~mm} \text { canula) }\end{array}$ & $\begin{array}{l}\text { Validated only } \\
\text { on abdomen site } \\
\text { (tangential insertion, } \\
13 \text { mm canula) }\end{array}$ & $\begin{array}{l}\text { Validated only on abdomen } \\
\text { site (tangential insertion, } \\
13 \text { mm canula) }\end{array}$ & $\begin{array}{l}\text { Abdomen, hip, } \\
\text { (14 mm canula }\end{array}$ & xternal part of thigh \\
\hline $\begin{array}{l}\text { Monitoring the } \\
\text { insertion site }\end{array}$ & \multicolumn{5}{|c|}{$\begin{array}{l}\text { Medtronic is the only one that allows monitoring of the puncture site (irritation...). The Minilink (transmitter) is not "fixed" to } \\
\text { the skin and additional intervention (Opsite) is required. For Dexcom and Navigator, the transmitter is clipped to a broad base but } \\
\text { there is no possible visual monitoring locally. Attaching the transmitter more securely in adolescents or adults during sports can } \\
\text { be useful because it can come loose from its base. }\end{array}$} \\
\hline $\begin{array}{l}\text { Sensor } \\
\text { specifications }\end{array}$ & $\begin{array}{l}\text { Storage }\left(3-30^{\circ} \mathrm{C}\right) \\
\text { Shelf life } 6 \text { months }\end{array}$ & & $\begin{array}{l}\text { ge }\left(2-25^{\circ} \mathrm{C}\right) \\
\text { life } 6 \text { months }\end{array}$ & $\begin{array}{l}\text { perature storage } \\
6 \text { months }\end{array}$ & $\begin{array}{l}\text { Storage }\left(2-27^{\circ} \mathrm{C}\right) \\
\text { Shelf life } 6 \text { months }\end{array}$ \\
\hline
\end{tabular}


Table 1 (end)

Devices allowing continuous glucose monitoring (CGM) in real time

$\begin{array}{ll}\begin{array}{l}\text { Transmitter } \\ \text { specifications }\end{array} & \text { Round lithium battery (watch), replace } \\ \text { monthly, transmitter lifetime 2 years }\end{array}$

specifications

Sensor insertion

Refuse

Software
2 years warranty; memory stores 60 days data/built in BG monitor/AAA batteries (lifetime of 60 days), capture of events (insulin, meals...)/easy access to data via displayed graphs/easy reading of data/pulldown menu with 10 items/icons alerts if problems with the sensor
Strict aseptic/sensor placement easy with the flexible serter/check tightness periodically on the transmitter/third person might be needed to remove the transmitter from the back of the arm/ensure the batteries are charged when inserting sensor (otherwise lost)

Serter \& sensor: all in one, but bulky

Easy and fast download, manipulation required to import \& export data COPILOT MANAGER
Silver oxide nonrechargeable battery (lifetime 18 months)/ small transmitter
Silver oxide nonrechargeable battery (lifetime 6 months)/small transmitter
1 year warranty/ access to last 9 hours graph/stand-alone unit/rechargeable batteries lifetime 3 to 5 days), capture of events (insulin, meals, exercise...), easy reading of data/ easy access to any item from the graph display screen/pulldown menu

Strict aseptic/serter easy to use/security lock is used to take off the transmitter

Serter \& sensor : all in one, but bulky

Download is easy, fast and intuitive/ reading of graphs: no indication of events on the glucose profiles

Data Manager 3

\section{4 year warranty/ memory stores 54 days data/monitor $=$ pump $/$ compatible with most BG monitors /1 AA Lithium battery/capture of events (insulin,meals, exercise...)/ easy reading of data/colour screen/easy access to any item from the graph display screen/pull-down menu}

Strict aseptic/serter easy to use/security lock is used to take off the transmitter

Serter \&sensor : all in one, but bulky

Internet platform DIASEND: Download is easy, fast and intuitive
Strict aseptic/serter easy to use/monitoring of puncture site possible

Battery rechargeable (40 times) (14 days or more use per charge, transmitter Minilink 1 year expected life if permanent use

1 year warranty/ memory stores 30 days data/monitor $=$ pump $/$ capture of events (insulin, meals...)/ easy access to any item from the graph display screen/pull-down menu

Serter reusable

Easy download and reading of data CARE LINK PRO and CARE LINK PERSO and monitoring patients with type 1 diabetes equipped with a CGM. This consensus will not consider professional CGM used for diagnostic and/or educational purpose.

\section{Description of the technology}

CGM devices consist of three parts: a glucose sensor, a transmitter and a receiver-monitor. The glucose sensor is inserted subcutaneously by the patient himself by means of a dedicated device. It has been shown to be reliable in measuring glucose for periods of 5 to 7 days, depending on the particular sensor. It detects and measures glucose by means of an enzyme called glucose oxidase which oxidizes the glucose in the interstitial fluid. The hydrogen peroxide produced is separated under the effect of an electric current to which the sensor is subjected; this generates an electrical signal proportional to the concentration of interstitial glucose.
Calibration of the signal with the simultaneous blood glucose level is necessary for the device to estimate the corresponding blood glucose level [22]. This calibration is required one to three times per day depending on the device. There is still a disparity between the blood glucose level estimated from the sensor signal and the actual blood glucose because of the physiological time lag between the concentration of interstitial glucose and blood glucose. This time lag grows in case of rapid glycaemic variation, which is why it is best to do the calibration when the blood glucose level is stable. A transmitter connected to the sensor transmits the signal via telemetry to a receiver-monitor. This receiver can be integrated into an insulin pump such as the Paradigm Veo ${ }^{\circledR}$, Medtronic, or more recently the Animas Vibe ${ }^{\circledR}$, Novalab; in this case the pump's screen is used as a monitor. In other cases, the receiver can be a stand-alone unit such as the Seven Plus ${ }^{\circledR}$, DexCom Inc. or the Navigator ${ }^{\circledR}$, Abbott, which can also be used as a glucose meter. 
Glucoday ${ }^{\circledR}$, another CGM device, made by A. Menarini Diagnostics, uses micro dialysis instead of an implanted glucose sensor. A buffer solution circulates in the subcutaneous interstitial fluid by means of an implanted microfiber which recovers the glucose by dialysis. The glucose is then measured by an enzyme in an extracorporeal device. This device, which is a monitor, serves to pump the buffer solution and continuously measure the glucose level. Its size, as well as the fragility of the microfiber, makes it difficult to use on outpatients.

The different devices available in France are summarized in Table 1.

\section{Review of the literature (EBM)}

\subsection{Clinical efficacy in adults with type 1 diabetes}

4.1.1. $H b A_{1 c}$

Real-time CGM informs its user of the estimated level of blood glucose every 1-5 minutes, or much more often than spot testing from SMBG. The information provided by CGM is constantly accessible and permits the patient to adjust daily insulin dosing, avoid unnoticed high or low glucose levels and thus improve his glucose control. In the studies, CGM significantly reduces $\mathrm{HbA}_{1 \mathrm{c}}$ by about $0.5 \%$ as compared to intermittent SMBG, provided that the patient uses CGM at least $40 \%$ of the prescribed time [19,23-26]. The results of these studies are detailed in Table 2. Use of CGM for less than $40 \%$ of the prescribed time denies the patient this improvement [23]. A recent meta-analysis confirms these results [27] and a Cochrane review appeared a short while ago [28]. The improvement is observed at 3 months [23] and maintained at 6 months [24], 12 months [26,29,30] and 18 months [24], the maximum follow- up of the studies to date. The improvement is observed whatever the initial level of $\mathrm{HbA}_{1 \mathrm{c}}$ is, whether the patient uses a pump or multiple daily injections [21] and however long a pump has previously been used by a particular patient. In the EVADIAC Sensor study [30], the reduction of $\mathrm{HbA}_{1 \mathrm{c}}$ at 12 months is greater in patients on a pump than in those on multiple injections.

Careful initial training of patients [21,32,33] and educational reinforcement [30] are also key elements in the improvement of $\mathrm{HbA}_{1 \mathrm{c}}$.

\subsubsection{Hypoglycaemia and glucose variability}

The possibility of setting a "low glucose" alarm at a variable threshold and an "impending hypoglycaemia" alarm is an interesting option, particularly with patients unaware of their low blood glucose. To date, no study has had as its principal objective the reduction of severe hypoglycaemias. Severe repeated hypoglycaemia [26] or hypoglycaemia unawareness [19] has even been among the exclusion criteria in certain studies. A study having as its principal objective the reduction of mild hypoglycaemias [35] demonstrates that the use of a CGM device for six months by patients with well-controlled type 1 diabetes $\left(\mathrm{HbA}_{1 \mathrm{c}}<7.5 \%\right)$ treated by pump (the majority) or multiple injections makes possible a reduction by half of the time spent in hypoglycaemia $(P=0.03)$ and a supplementary improvement of $\mathrm{HbA}_{1 \mathrm{c}}(-0.27 \%, P=0.0008)$ [35]. Another study recruited a small number of patients on the basis of frequency of hypoglycaemia (more than 6 episodes $<60 \mathrm{mg}$ / $\mathrm{dl}$ in the last 15 days) and showed a $50 \%$ reduction in the frequency of hypoglycaemias and a simultaneous reduction in $\mathrm{HbA}_{1 \mathrm{c}}$ when a CGM device as opposed to SBMG is used for three months [36].

The analysis at 6 months of the group of 129 patients with good glucose control $\left(\mathrm{HbA}_{1 \mathrm{c}}<7 \%\right)$ included in the JDRF study [11] shows a reduction by half in the number of hypoglycaemias $<60 \mathrm{mg} / \mathrm{dl}(P=0.05)$ in the CGM group despite a reduction in $\mathrm{HbA}_{1 \mathrm{c}}(6.4$ vs $6.8 \%, P<0.001)$ and reduced glucose variability as shown by the standard deviation of glucose values $(P=0.03)$, with no difference in the mean amplitude of glycaemic excursions (MAGE). The improvement lasts between the 6th and the 12th month in the follow-up of the adult group in the JDRF study with a reduction of severe hypoglycaemias (from 21.8 to 7.1 events per 100 personyears) - a reduction more pronounced in patients having $\mathrm{HbA}_{1 \mathrm{c}}$ $<7 \%-$ and a reduced glucose variability (standard deviation of glucose values, $P=0.02$, and MAGE, $P=0.03$ ) [29]. The Real trend [25] and EVADIAC Sensor [30] studies find a reduction in the glycaemic variability (standard deviation of glucose values respectively $P=0.005$ and $P=0.018$ ) with no change in the number of hypoglycaemias (Table 3 ).

More recently, the Paradigm VEO ${ }^{\circledR}$ pump is automatically capable of temporarily interrupting the infusion of insulin if the glucose level falls below an adjustable threshold. To date, there has been little evaluation of the efficacy and safety of this function in the prevention of severe hypoglycaemias $[37,38]$.

\subsubsection{Quality of life and satisfaction with treatment}

Two more general factors - illness-associated quality of life (QoL) and satisfaction with treatment-complement the issues of safety and efficacy in the management of a chronic disease like type 1 diabetes. They contribute notably to adherence to this management. Improvement of glucose control and stability or a reduction in hypoglycaemia events can be positive effects of CGM in terms of QoL and satisfaction. On the other hand, permanent use of the device, the triggering of sometimes false alarms and the constant viewing of glucose variations can negatively affect them. The impact of CGM on the QoL of diabetic patients remains a domain requiring exploration by large studies using validated questionnaires. Some data are available in the literature. They show no degradation of QoL with CGM in adult type 1 diabetics [30,39,40], children [41] or children and adults [42]. Two studies have found no difference in QoL between CGM and traditional self-monitoring [40].

Both the global score measuring the fear of hypoglycaemias (HFS global) and the score measuring behaviours capable of preventing hypoglycaemias (HFS behaviour) are improved in adult patients on CGM $[42,43]$. In the JDRF 
Table 2

Results in $\mathrm{HbA}_{\mathrm{cc}}$ in Randomised Controlled Trials (RCT) comparing personal continuous glucose monitoring (CGM) to self- monitoring of blood glucose (SMBG) in type 1 diabetic patients treated with a pump or multiple daily insulin injections (MDI)

\begin{tabular}{|c|c|c|}
\hline $\begin{array}{l}\text { Studies } \\
\text { Duration } \\
\text { Countries }\end{array}$ & $\begin{array}{l}\text { Type } 1 \text { diabetic patients } \\
\text { Study Group } \\
\text { Baseline } \mathrm{HbA}_{1 \mathrm{c}} \text { (mean) }\end{array}$ & $\begin{array}{l}\mathrm{HbA}_{1 \mathrm{c}} \text { Results } \\
\text { Difference CGM vs control group }\end{array}$ \\
\hline $\begin{array}{l}\text { Guard control, } 2006 \\
3 \text { months [23] } \\
\text { Europe + Israel }\end{array}$ & $\begin{array}{l}\mathrm{n}=162(50 \% \text { adults }) \\
\text { Baseline } \mathrm{Hb} \mathrm{A}_{1 \mathrm{c}} \geq 8,1 \%(9.6 \%) \\
\text { Pump }(\mathrm{n}=78) \text { or MDI }(\mathrm{n}=84) \\
\text { CGM (Guardian RT) continuous, intermittent vs SMBG }\end{array}$ & $-0.6 \%, P=0.003$ \\
\hline $\begin{array}{l}\text { JDRF, } 2008 \\
6 \text { months }[24] \\
\text { USA }\end{array}$ & $\begin{array}{l}\mathrm{n}=322(3 \text { age groups }) \\
\text { Baseline } \mathrm{HbA}_{1 \mathrm{c}} 7-10 \%(7.6 \%) \\
\text { Majority on pump }(\approx 80 \%) \\
\text { CGM vs SMBG }\end{array}$ & $\begin{array}{l}-0,53 \% \text { if older than } 25, P<0.001 \\
\text { No difference in age } 15-24\end{array}$ \\
\hline $\begin{array}{l}\text { STAR } 1,2008 \\
6 \text { mois [19] } \\
\text { USA }\end{array}$ & $\begin{array}{l}\mathrm{n}=146(71 \% \text { adults }) \\
\text { Baseline } \mathrm{HbA}_{1 \mathrm{c}} \geq 7.5 \%(\approx 8.4 \%) \\
\text { On pump only } \\
\text { CGM vs SMBG }\end{array}$ & $\begin{array}{l}\text { No difference } \\
\text { Significant lowering only with patients adhering } \\
\text { to CGM (> } 60 \% \text { of the time) }\end{array}$ \\
\hline $\begin{array}{l}\text { JDRF } 2009 \\
6 \text { months }[11] \\
\text { USA }\end{array}$ & $\begin{array}{l}\mathrm{n}=129 \\
\mathrm{HbA}_{1 \mathrm{c}}<7 \%(\approx 6.5 \%) \\
\text { pump }(93 \% \text { CGM group and } 79 \% \text { SMBG group) or multiple injections } \\
\text { CGM vs SMBG }\end{array}$ & $-0.34 \%, P<0.001$ \\
\hline $\begin{array}{l}\text { O'Connell, } 2009 \\
3 \text { months [32] } \\
\text { Australia }\end{array}$ & $\begin{array}{l}\mathrm{n}=62(50 \% \text { over age } 19) \\
\text { Baseline } \mathrm{HbA}_{1 \mathrm{c}} \leq 8.5 \%(\approx 7.4 \%) \\
\text { Pump only } \\
\text { CGM vs SMBG }\end{array}$ & $-0.43 \%, P=0.009$ \\
\hline $\begin{array}{l}\text { Real Trend, } 2009 \\
6 \text { months }[25] \\
\text { France }\end{array}$ & $\begin{array}{l}\mathrm{n}=132(61 \% \text { adults }) \\
\text { Baseline } \mathrm{HbA}_{1 \mathrm{c}} \geq 8 \%(\approx 9.4 \%) \\
\text { MDI at start } \\
\text { Pump + CGM vs pump + SMBG }\end{array}$ & $\begin{array}{l}\text { No difference in intention to treat } \\
\text { Analysis per protocol : }-0.41 \%, P=0.004 \text { with } \\
\text { patients adhering to CGM }(>70 \% \text { of the time })\end{array}$ \\
\hline $\begin{array}{l}\text { STAR } 3,2010 \\
12 \text { months }[31] \\
\text { USA }\end{array}$ & $\begin{array}{l}\mathrm{n}=485(67 \% \text { adults }) \\
\text { Baseline } \mathrm{HbA}_{1 \mathrm{c}}>7.4 \%(8.3 \%) \\
\text { Pump + CGM vs MDI + SMBG }\end{array}$ & $\begin{array}{l}-0.6 \%, P<0,01 \text { vs MDI }+ \text { ASG } \\
\text { (adherence }>80 \% \text { of the time) }\end{array}$ \\
\hline $\begin{array}{l}\text { Eurythmics, } 2011 \\
6 \text { months [34] } \\
\text { Europe }\end{array}$ & $\begin{array}{l}\mathrm{n}=83 \\
\text { Baseline } \mathrm{HbA}_{1 \mathrm{c}}>8.2 \%(8.5 \%) \\
\text { Pump + CGM vs MDI + SMBG }\end{array}$ & $\begin{array}{l}-1.23 \% \text { vs }-0.13 \% \text { in the control group, } P<0.001 \\
\text { ( } 79 \% \text { of the patients were using the sensor } \\
\text { more than } 60 \% \text { of the time) }\end{array}$ \\
\hline $\begin{array}{l}\text { Battelino T, } 2011 \\
6 \text { months [35] } \\
\text { Europe, Israel }\end{array}$ & $\begin{array}{l}\mathrm{n}=120(55 \% \text { adults }) \\
\text { Baseline } \mathrm{HbA} \mathrm{Ac}_{\mathrm{lc}}<7.5 \%(6.9 \%) \\
\text { Pump }(50 \% \text { control group, } 75 \% \text { study group }) \text { or multiple injections } \\
\text { CGM vs SMBG }\end{array}$ & $\begin{array}{l}-0.27, P=0.008 \\
\text { Primary end point: hypoglycaemia }\end{array}$ \\
\hline $\begin{array}{l}\text { EVADIAC sensor, } 2011 \\
12 \text { months [30] } \\
\text { France }\end{array}$ & $\begin{array}{l}\mathrm{n}=178(84 \% \text { adults }) \\
\text { Baseline } \mathrm{HbA}_{1 \mathrm{c}}>8 \%(9 \%) \text { pump or multiple injections }(\approx 50 \%) \\
\text { CGM vs SMBG }\end{array}$ & $\begin{array}{l}-0,5 \% \text { in "ad libitum" CGM group } \\
-0,45 \% \text { in "intermittent" group ( }>50 \% \text { of the time), } \\
P=0.0006\end{array}$ \\
\hline
\end{tabular}

study [43], there is no change in QoL in the paediatric population, either in parents or children. "Satisfaction" was rather good in children, parents and adults, with the greatest satisfaction among those who used CGM most assiduously, at least 6 days out of 7 [42]. The EVADIAC Sensor study showed, after a year of use of CGM, an improvement in physical well-being (questionnaire SF36).

\subsubsection{Specific suggestions-Pregnancy: Gestational and "pregestational" diabetes}

No data published today support the use over the course of pregnancy of personal CGM. On the other hand, data from the literature on the use of professional CGM show the following results: 


\section{Table 3}

Results showing the frequency and duration of low glucose events in randomised controlled trials (RCT) comparing personal continuous glucose monitoring (CGM) to self-monitoring of blood glucose (SMBG) in type 1 diabetic patients treated with a pump or multiple daily insulin injections (MDI). $\mathrm{NS}=$ non-significant.

\begin{tabular}{|c|c|c|}
\hline $\begin{array}{l}\text { Studies } \\
\text { Duration } \\
\text { Countries }\end{array}$ & $\begin{array}{l}\text { Type } 1 \text { diabetic patients } \\
\text { Study Group } \\
\text { Baseline } \mathrm{HbA}_{1 \mathrm{c}} \text { (mean) }\end{array}$ & $\begin{array}{l}\text { Results on hypoglycaemia events } \\
\text { Difference CGM vs control group }\end{array}$ \\
\hline $\begin{array}{l}\text { Guard control, } 2006 \\
3 \text { months [23] } \\
\text { Europe + Israel }\end{array}$ & $\begin{array}{l}\mathrm{n}=162(50 \% \text { adults }) \\
\text { Baseline } \mathrm{HbA} \mathrm{fc}_{\mathrm{cc}} \geq 8.1 \%(9.6 \%) \\
\text { With pump }(\mathrm{n}=78) \text { or } \mathrm{MDI}(\mathrm{n}=84) \\
\text { CGM (Guardian RT) continuous, intermittent vs SMBG }\end{array}$ & $\begin{array}{l}\text { No data on mild hypoglycaemia } \\
\text { Area under curve hypo, NS } \\
1 \text { severe hypoglycaemic event in each group }\end{array}$ \\
\hline $\begin{array}{l}\text { JDRF, } 2008 \\
6 \text { months [24] } \\
\text { USA }\end{array}$ & $\begin{array}{l}\mathrm{n}=322(3 \text { age groups }) \\
\text { Baseline } \mathrm{HbA}_{\mathrm{cc}} 7-10 \%(7.6 \%) \\
\text { Majority on pump }(\approx 80 \%) \\
\text { CGM vs SMBG }\end{array}$ & $\begin{array}{l}\text { Rare severe hypoglycaemic event } \\
\text { Mild or severe hypoglycaemic events: } \\
\text { comparable in both groups }\end{array}$ \\
\hline $\begin{array}{l}\text { STAR 1, } 2008 \\
6 \text { months [19] } \\
\text { USA }\end{array}$ & $\begin{array}{l}\mathrm{n}=146(71 \% \text { adults }) \\
\text { Baseline } \mathrm{HbA} \mathrm{Ac}_{1 \mathrm{c}}>7.5 \%(\approx 8.4 \%) \\
\text { Pump only } \\
\text { CGM vs SMBG }\end{array}$ & More severe hypoglycaemic events in CGM group \\
\hline $\begin{array}{l}\text { O’Connell, } 2009 \\
3 \text { months [32] } \\
\text { Australia }\end{array}$ & $\begin{array}{l}\mathrm{n}=62(50 \% \text { over age } 19) \\
\text { Baseline } \mathrm{HbA}_{1 \mathrm{c}} \leq 8.5 \%(\approx 7.4 \%) \\
\text { Pump only } \\
\text { CGM vs SMBG } \\
\text { Severe hypoglycaemic events excluded }\end{array}$ & Number of mild hypoglycaemia events comparable \\
\hline $\begin{array}{l}\text { JDRF } 2009 \\
6 \text { months [11] } \\
\text { USA }\end{array}$ & $\begin{array}{l}\mathrm{n}=129 \\
\mathrm{HbA}_{1 \mathrm{c}}<7 \%(\approx 6.5 \%) \\
\text { Pump }(93 \% \text { g CGM group and } 79 \% \text { SMBG group) } \\
\text { or multiple injections } \\
\text { CGM vs SMBG }\end{array}$ & $\begin{array}{l}\text { Reduction of time (area under the curve })<60 \mathrm{mg} / \mathrm{dl} \\
(P=0.02) \text { or }<50 \mathrm{mg} / \mathrm{dl}(P=0.04)\end{array}$ \\
\hline $\begin{array}{l}\text { Real Trend, } 2009 \\
6 \text { months [25] } \\
\text { France }\end{array}$ & $\begin{array}{l}\mathrm{n}=132(61 \% \text { adults }) \\
\text { Baseline } \mathrm{HbA}_{1 \mathrm{c}} \geq 8 \%(\approx 9.4 \%) \\
\text { MDI at start } \\
\text { Pump+ CGM vs pump + SMBG }\end{array}$ & Number of hypoglycaemic events comparable \\
\hline $\begin{array}{l}\text { STAR } 3,2010 \\
12 \text { months [31] } \\
\text { USA }\end{array}$ & $\begin{array}{l}\mathrm{n}=485(67 \% \text { adults }) \\
\text { Baseline } \mathrm{HbA}_{1 \mathrm{c}}>7.4 \%(8.3 \%) \\
\text { Pump + CGM vs MDI+SMBG }\end{array}$ & $\begin{array}{l}\text { No data for mild or severe hypoglycaemic events } \\
\text { Area under the curve }<70 \mathrm{mg} / \mathrm{dl} \text { et }<50 \mathrm{mg} / \mathrm{dl} \text {, NS }\end{array}$ \\
\hline $\begin{array}{l}\text { Battelino T, } 2011 \\
6 \text { months [35] } \\
\text { Europe, Israel }\end{array}$ & $\begin{array}{l}\mathrm{n}=120(55 \% \text { adults }) \\
\text { Baseline } \mathrm{HbA}_{1 \mathrm{c}}<7.5 \%(6.9 \%) \\
\text { Pump }(50 \% \text { control group, } 75 \% \text { study group }) \\
\text { or multiple injections } \\
\text { CGM vs SMBG }\end{array}$ & $\begin{array}{l}\text { Reduction of the number of glucose levels }<63 \mathrm{mg} / \mathrm{dl}, \\
P=0.02 \text { and time }<70 \mathrm{mg} / \mathrm{dl}, P=0.01\end{array}$ \\
\hline $\begin{array}{l}\text { EVADIAC sensor, } 2011 \\
12 \text { months [30] } \\
\text { France }\end{array}$ & $\begin{array}{l}\mathrm{n}=178(84 \% \text { adults }) \\
\text { Baseline } \mathrm{HbA}_{\mathrm{lc}}>8 \%(9 \%) \\
\text { Pump or multiple injections }(\approx 50 \%) \\
\text { CGM vs SMBG }\end{array}$ & $\begin{array}{l}\text { No difference in mild or severe hypoglycaemic events } \\
P=0.1682\end{array}$ \\
\hline
\end{tabular}

- professional CGM makes it possible to diagnose missed peaks of hyperglycaemia in postprandial periods during pregnancy, both in gestational and pre-existing type 1 diabetes $[44,45]$;

- the repeated use (5 to 7 days every 4 to 6 weeks) of CGM in the course of pregnancy improves $\mathrm{HbA}_{1 \mathrm{c}}$ and reduces the risk of macrosomia in both type 1 and type 2 diabetes [46].

These findings favour the intermittent and repeated use of CGM in pregnant patients with pregestational diabetes (Grade $B$ recommendation).

\subsection{Clinical efficacy in children and adolescents with type 1 diabetes}

Twelve randomized controlled trials of CGM involving children and adolescents with type 1 diabetes, on a pump or multiple injections, were done from 2006 to 2011. Seven of the studies focus on adults and children/ adolescents and four focus only on a paediatric population $[24,31,47,48]$. The international recommendations on the use of CGM with children and adolescents have just been published [49]. 
4.2.1. $H b A_{1 c}$

The synthesis of the results of the randomized trials in populations of children and adolescents is reported in Table 4 . In intention to treat (ITT), the results are significant in 7 studies in patients with good or bad glucose control at baseline $[11,35]$. In several studies, the improvement in $\mathrm{HbA}_{1 \mathrm{c}}$ is comparable in children or adolescents and adults [23,31,32,50]. This is not the case in the paediatric groups in the JDRF study [24]: compared to adults, the paediatric population had less good adherence to the use of sensors $(83 \%$ of adults vs $50 \%$ of children and $30 \%$ of adolescents). The studies all show a significant relation between a decrease in $\mathrm{HbA}_{1 \mathrm{c}}$ and frequency of use of sensors. When the results are analysed in terms of adherence to the use of sensors (analysis per protocol), the decrease in $\mathrm{HbA}_{1 \mathrm{c}}$ is significant whatever the age (on average $-0.53 \%$, ranging from -0.3 to $-0.8 \%$ ). The rate of paediatric patients having an optimal adherence in these studies varies considerably, from $15-20 \%$ (in the JRDF adolescent group and the DirecNet group of very young children) to more than $70 \%[23,50]$.

\subsubsection{Hypoglycaemia and glucose variability}

Only one randomized controlled trial has for its principle objective analysis of the impact of CGM on the frequency of hypoglycaemic events. It shows a significant reduction of hypoglycaemic events in patients, both adults and children, whose $\mathrm{HbA}_{1 \mathrm{c}}$ is below $7.5 \%$ at baseline. In all the other randomized controlled trials, the frequency of hypoglycaemic events is a secondary objective. The frequency is either reduced [50] or - most often - not increased when the $\mathrm{Hb}_{1 \mathrm{c}}$ drops. Glucose variability is rarely studied and the criteria of measurement differ. The Onset Trial paediatric study shows a reduction in MAGE with the sensor-augmented pump vs the pump and SMBG [47].

\subsubsection{Satisfaction with treatment and quality of life}

These parameters are often evaluated and in all cases are secondary outcomes of trials. Satisfaction with treatment is high among parents and children with type 1 diabetes, whether the control of diabetes is improved [51] or not (evidencing the importance of low glucose alarms in particular in young children) [48]. The Onset Trial study shows, with validated QoL scales, an improvement in well-being and QoL in children and a decrease in parental depression in the year following the diagnosis, in comparison with the group receiving the same treatment with pumps without sensors [47]. Finally, it is interesting to note that the group of children treated with sensors in the Switch study shows a significant reduction in absences from school [50].

\subsection{Cost-utility analysis of CGM}

CGM is thus an effective tool but it is expensive. A good cost-utility ratio for CGM is particularly important where reimbursement is to be obtained for the device. Two studies have evaluated this ratio $[53,54]$.
Two criteria are used in evaluating the cost-utility ratio:

- QALYs (quality-adjusted life years) measure the burden of an illness. This score is based on the metabolic improvement obtained by the intervention - in this case, CGM - and on the long-term extrapolation of that improvement -i.e., the evolution of QoL and mortality - inspired by two large interventional studies, the DCCT $[1,4]$ and the UKPDS [55]. Each year passed in perfect health corresponds to a score of 1 , adjusted from 0 to 1 according to the QoL;

- the ICER (incremental cost-effectiveness ratio) represents the cost per QALY of a therapeutic intervention.

The two studies find a comparable and acceptable gain in QALYs and ICER. Thus CGM is a worthwhile tool in the long term, although questions remain as to whether the metabolic gain continues after many years of utilisation of the device. The EVADIAC Sensor study [30] at 1 year and the Star 3 study [31] at 18 months are reassuring in this regard. Moreover, in the EVADIAC Sensor study, step-bystep utilisation (progressive increase of the time of CGM use according to its effectiveness) yields a benefit equal to ad libitum use, with a $30 \%$ savings in sensors. In the past two years, CGM has been reimbursed by the health-care systems in certain countries such as Sweden (2009), Holland (2010), Slovenia (2010), Israel (2011) and Switzerland (2011) [56]. Each country has recommended indications mainly for patients with type 1 diabetes: adults with poor glucose control or hypoglycaemia, children and adolescents, and pregnant women. In France, CGM is not yet reimbursed by health insurance. The monthly cost of the consumables, not including the device, when use is continuous is about 300 Euros, plus tax.

\section{Recommended indications}

In light of the literature and the deliberations of a panel of experts, indications for CGM in type 1 diabetes can be proposed. The level of evidence is variable, however:

- the effectiveness of CGM is significantly correlated to the length of time sensors are used [24,31,32,52]. Efforts to increase sensor use are important, particularly in the paediatric population. A CGM trial period of generally less than one month should be proposed to candidates. Evaluation at 1 month almost always makes it possible to tell if a patient has been adhering to sensor use, accepts the constraints imposed by the method and sees its advantages. In certain cases to be discussed, the trial period for overcoming the initial obstacles to acceptance of a supplementary device and to mastering its use can be justifiably extended (to 3 months at most).

- the recommended indications for CGM are:

- a type 1 adult diabetic who - notwithstanding intensive treatment and management involving multiple injections or a pump, appropriate therapeutic education and SMBG several times a day, presents: 
Table 4

Personal CGM in RCT in paediatric populations. $\mathrm{HbA}_{1 \mathrm{c}}$ difference between the CGM group and the SMBG group at the end of the study

\begin{tabular}{|c|c|c|c|}
\hline $\begin{array}{l}\text { Studies } \\
\text { Duration } \\
\text { Countries }\end{array}$ & $\begin{array}{l}\text { Type } 1 \text { diabetic patients } \\
\text { Study Group } \\
\text { Baseline } \mathrm{HbA}_{1 \mathrm{c}} \text { (mean) }\end{array}$ & $\begin{array}{l}\mathrm{HbA}_{1 \mathrm{c}} \text { results } \\
\text { Difference (in ITT) CGM } \\
\text { vscontrol group }\end{array}$ & $\begin{array}{l}\mathrm{HbA}_{1 \mathrm{c}} \text { results Difference } \\
\text { (per protocol analysis) CGM } \\
\text { vscontrol. group }\end{array}$ \\
\hline $\begin{array}{l}\text { Guard control, } 2006 \\
3 \text { months [23] } \\
\text { Europe + Israel }\end{array}$ & $\begin{array}{l}\mathrm{n}=162(50 \% \text { children }) \\
\text { Baseline } \mathrm{HbA} \mathrm{A}_{1 \mathrm{c}}>8,1 \%(9.6 \%) \\
\text { Pump) or MDI } \\
\left.\text { CGM (Guardian }{ }^{\circledR} \mathrm{RT}\right) \text { continuous, } \\
\text { intermittent vs SMBG }\end{array}$ & $\begin{array}{l}-0.60 \%, P<0.003 \\
\text { Children \& adults }\end{array}$ & $\begin{array}{l}\text { Use of sensor }>85 \% \text { time in } \\
\text { adults, children and adolescents }\end{array}$ \\
\hline $\begin{array}{l}\text { JDRF, } 2008 \\
6 \text { months [24] } \\
\text { USA }\end{array}$ & $\begin{array}{l}\mathrm{n}=322 \\
(3 \text { age groups, } 33 \% \text { children and } 34 \% \text { adolescents) } \\
\text { Baseline } \mathrm{HbA}_{1 \mathrm{c}} 7-10 \%(8 \% \text { in both) } \\
\text { Majority on pump }(\approx 80 \%) \\
\text { CGM ( } 3 \text { different devices) vs SMBG }\end{array}$ & $\begin{array}{l}\text { Ado }+0.08 \%, \text { NS } \\
\text { Children }-0.13 \%, \text { NS }\end{array}$ & $\begin{array}{l}\text { Significant benefit in all groups } \\
(-0.5 \text { à }-0.7 \%) \text { if use of sensor } \\
\geq 6 \mathrm{~d} / 7(P<0.01)[52]\end{array}$ \\
\hline $\begin{array}{l}\text { STAR 1, } 2008 \\
6 \text { months [19] } \\
\text { USA }\end{array}$ & $\begin{array}{l}\mathrm{n}=146(29 \% \text { children }) \\
\text { Baseline } \mathrm{HbA} \mathrm{Ac}_{\mathrm{cc}} \geq 7.5 \%(\approx 8.4 \%) \\
\text { Pump only } \\
\text { CGM vs SMBG }\end{array}$ & NS & $\begin{array}{l}\text { Correlation duration of use } \\
>60 \% \text { and } \mathrm{HbA}_{1 \mathrm{c}} \text { reduction } \\
(P=0.045)\end{array}$ \\
\hline $\begin{array}{l}\text { O’Connell } 2009 \\
3 \text { months [32] } \\
\text { Australia }\end{array}$ & $\begin{array}{l}\mathrm{n}=62(50 \% \text { between age } 13 \text { and } 19) \\
\text { Baseline } \mathrm{HbA}_{1 \mathrm{c}} \leq 8.5 \%(\approx 7.4 \%) \\
\text { Pump only } \\
\text { CGM }\left(\text { Paradigm }{ }^{\circledR} \mathrm{RT}\right) \text { vs SMBG }\end{array}$ & $-0.43 \%, P<0.009$ & $\begin{array}{l}-0.50 \% \text { when use }>70 \% \text { time } \\
(P=0.04)\end{array}$ \\
\hline $\begin{array}{l}\text { JDRF, } 2009 \\
6 \text { months [11] } \\
\text { USA }\end{array}$ & $\begin{array}{l}\mathrm{n}=129(25 \% \text { children et adolescents }) \\
\text { Baseline } \mathrm{HbA}_{1 \mathrm{c}}<7 \%(\approx 6.5 \%)\end{array}$ & $-0.34, P<0.01$ & \\
\hline $\begin{array}{l}\text { Real Trend, } 2009 \\
6 \text { months }[25] \\
\text { France }\end{array}$ & $\begin{array}{l}\mathrm{n}=132(39 \% \text { children }) \\
\text { Baseline } \mathrm{HbA}_{1 \mathrm{c}} \geq 8 \%(\approx 9.4 \%) \\
\text { Multiple injections initially } \\
\left.\text { Pump + CGM (Paradigm }{ }^{\circledast} \mathrm{RT}\right) \text { vs pump + SMBG }\end{array}$ & $-0.24 \%,(\mathrm{NS})$ & $\begin{array}{l}-0.41 \% \text { if used }>70 \% \text { time } \\
(P=0.04)\end{array}$ \\
\hline $\begin{array}{l}\text { STAR 3, } 2010 \\
12 \text { months [31] } \\
\text { USA }\end{array}$ & $\begin{array}{l}\mathrm{n}=485(3 \text { age groups, } 32 \% \text { children }) \\
\text { Baseline } \mathrm{HbA}_{1 \mathrm{c}}>7.4 \%(8.3 \%) \\
\text { Pump + CGM }\left(\text { Paradigm }{ }^{\otimes} \mathrm{RT}\right) \text { vs MDI + SMBG }\end{array}$ & $\begin{array}{l}\text { Adults }-0.60 \%, P<0.001 \\
\text { Children } \& \text { adolescents } \\
-0.5 \%, P<0.001\end{array}$ & $\begin{array}{l}\text { Correlation frequency of use } \\
\text { and } \mathrm{HbA}_{1 \mathrm{c}} \text { reduction } P=0.003\end{array}$ \\
\hline $\begin{array}{l}\text { Onset Trial, } 2010 \\
12 \text { months [47] } \\
\text { Europe }\end{array}$ & $\begin{array}{l}\text { Age at diagnosis }=1-16 \\
\mathrm{HbA}_{1 \mathrm{c}}=11.3 \% \\
\text { Pump vs pump }+\mathrm{CGM}\end{array}$ & $-0.2 \%(\mathrm{NS})$ & $\begin{array}{l}-0,5 \% \text { when CGM adherence } \\
>3 \text { days a week }(P=0.032)\end{array}$ \\
\hline $\begin{array}{l}\text { Battelino T, } 2011 \\
6 \text { mois [35] } \\
\text { Europe, Israel }\end{array}$ & $\begin{array}{l}\mathrm{n}=120(45 \% \text { children }) \\
\text { Age: } 10-17,9 \\
\text { Baseline } \mathrm{HbA}_{\mathrm{lc}}<7.5 \%(6.9 \%) \text { main objective: } \\
\text { hypoglycaemia } \\
\text { Pump or multiple injections } \\
\text { CGM vs SMBG }\end{array}$ & $-0.27 \%, P=0.008$ & $\begin{array}{l}\text { Mean duration CGM use for } \\
\text { children } 5.6 \text { et } 6 \mathrm{~d} / \mathrm{w}\end{array}$ \\
\hline $\begin{array}{l}\text { EVADIAC sensor, } \\
2011 \\
12 \text { months [30] } \\
\text { France }\end{array}$ & $\begin{array}{l}\mathrm{n}=178(13.5 \% \text { adolescents }) \\
\text { Baseline } \mathrm{HbA}_{1 \mathrm{c}}>8 \%(9 \%) \\
\text { Pump or multiple injections } \\
(\approx 50 \%) \\
\text { CGM vs SMBG }\end{array}$ & $-0.50 \%, P<0.0001$ & ND \\
\hline $\begin{array}{l}\text { Switch, } 2011 \\
14 \text { months [50] } \\
\text { Europe }\end{array}$ & $\begin{array}{l}\mathrm{n}=153(47 \%) \\
\mathrm{HbA}_{1 \mathrm{c}}=8.4 \% \\
\text { Cross over } 6 \text { months }\end{array}$ & $\begin{array}{l}\text { Children } \& \text { adolescents } \\
-0.46 \%, P<0.001\end{array}$ & Sensor use $73.1 \%$ \\
\hline $\begin{array}{l}\text { DirecNet Young } \\
\text { children, } 2011 \\
6 \text { months [48] } \\
\text { USA }\end{array}$ & $\begin{array}{l}\mathrm{n}=146 \text { children (age } 4-9) \\
\mathrm{HbA}_{1 \mathrm{c}}=7.9 \% \\
\text { Pump }(64 \%) \text { or multiple injections } \\
\text { CGM vs SMBG }\end{array}$ & $-0.10(\mathrm{NS})$ & $\begin{array}{l}-0.3 \%(P=0.01) \text { when sensor } \\
\text { use } \geq 6 \text { days out } 7\end{array}$ \\
\hline
\end{tabular}


1. an $\mathrm{HbA}_{1 \mathrm{c}}$ over the target fixed by the French recommendations (www.has-sante.fr). Grade A;

2. and/or undetected or frequent mild hypoglycaemias, particularly nocturnal ones. Grade B;

3. and/or frequent severe hypoglycaemias. Professional agreement;

4. in the course of pregnancy or preparation for pregnancy, recommended $\mathrm{HbA}_{1 \mathrm{c}}$ targets unattained or attained at the cost of mild frequent hypoglycaemias. Professional agreement;

- children and adolescents with type 1 diabetes who, notwithstanding treatment and extensive management, have:

1. an $\mathrm{HbA}_{1 \mathrm{c}}$ over the target fixed by the recommendations (www.has-sante.fr). Grade B;

2. and/or undetected or frequent mild hypoglycaemias, particularly nocturnal ones. Grade B;

3.and/or severe hypoglycaemias. Professional agreement.

\section{Contraindications of CGM}

There is no contraindication for the use of CGM. However, lack of use or inappropriate use of CGM [20] despite an accurate initial indication and educational reinforcement should raise questions about the validity of its continuance.

\section{Guidelines for CGM}

The success of CGM depends on the selection, training and follow-up of the patient.

\subsection{Selection of the patient}

Use of CGM requires that the patient be heavily involved in the management of his treatment:

- a trial period of 15 days to 1 month should be proposed to every candidate for CGM. This period makes it possible to choose motivated patients capable of using and wearing the CGM device - in other words, responsive patients. Indeed, CGM use in the first month is predictive of subsequent use [52] and the device is typically abandoned during this period [30]. In the EVADIAC Sensor study, about one-quarter of the patients were not randomized at the end of this period;

- metabolic effectiveness depends on CGM being used at least $40 \%$ of the time. However, metabolic benefit from CGM does not require permanent use of the device [30]. The optimal duration and the frequency of use of the device (a sensor every 15 days, 15 days of downloads out of 30, etc.) are not known and must be personalised, as the EVADIAC Sensor study has shown [30];

- the profile of "responsive" patients who make the best use of CGM has not been clearly determined [52]. Nevertheless, all patients included in the studies did a minimum of 3 SMBG daily, besides those necessary for the calibration of certain devices. All the patients had an optimized insulin regimen - pump or multiple injections. CGM benefits both populations. In the EVADIAC Sensor study [30], the benefit in terms of $\mathrm{HbA}_{1 \mathrm{c}}$ is more pronounced in patients on the pump. There is no study having for its principal objective a comparison of the effectiveness of CGM in patients on the pump or multiple injections.

\subsection{Training of the patient}

A program of specific therapeutic education must be conducted by a medical team with expertise in the new technologies and particularly CGM. Technical training of the patient involves the correct placement and calibration of the sensor and navigation of the monitor with attention in particular to the setting of alarms. This training can be done by a specifically trained nurse. The different studies all emphasize how important it is that patients who are candidates for CGM be specifically trained at the outset in the interpretation and appropriate use of the data to adjust their treatment. More time is necessary for this twofold training - diabetological and technical - in the paediatric population, given the diversity of those involved with the child (parents, teachers, day-care providers, etc.).

\subsection{Patient follow-up}

A re-evaluation of the benefit/risk/cost ratio of CGM must be done at 1 month (the trial period) and 3 months later for a decision to be made as to CGM's continuance. Subsequently, an annual re-evaluation will help determine the importance of extending the use of CGM.

Suspension of the use of CGM on the advice of the physician or at the request of the patient doesn't contraindicate a later attempt, after a certain delay, if the patient's motivation and medical situation justify it.

These different stages are detailed in the appendix.

\section{Conclusion and outlook}

CGM is a new technological tool for the therapeutic management of diabetes. It is still in development. Because the self-management of their treatment is difficult, diabetic patients treated with insulin and especially patients with type 1 diabetes seem to be the population most likely to question the clinical application of CGM. The great potential educational benefit of CGM should nevertheless encourage the evaluation of its usefulness in other forms of diabetes in the years ahead.

The advances achieved in the development of the technique have made possible its clinical evaluation in numerous randomized controlled trials involving adults and children. To these may be added data obtained by observation of certain specific conditions such as severe or frequent mild hypoglycaemias and pregnancy.

The results point to the conclusion that the increased information given by CGM to the patient about his glucose 
level variations can enable him to improve glucose control, reduce low glucose events and glucose variability and, by the combination of the two, improve the QoL associated with the illness. The extent to which these benefits can be obtained depends on the actual use of the device (adherence) and on the interpretation of data to make positive changes in treatment management (education).

It follows from this that the recommended indications for CGM, based on the level of evidence and the professional consensus, can be validated at the individual level only after a probative evaluation of the patient's adherence and the use he makes of the CGM data. Reimbursement by health insurance of CGM must take these considerations into account, given the development and cost of the technology. Guidelines for this reimbursement therefore need to be written to ensure that all eligible patients benefit from the technology and to prevent its continued use in cases where it is inappropriate or dangerous.

The current restrictions on the use of CGM will have to be revised as the technology progresses and as CGM is integrated into the management of insulin therapy.

The anticipated development of glucose sensors that will be more reliable because of better biocompatibility, more stable (permitting long-term implantation) or less invasive (permitting percutaneous measurement of glucose) is bound to facilitate access to CGM and adherence to it.

The prospects for CGM's integration will be enhanced when it can be made available in a computer environment that can offer therapeutic advice to the user. The development of algorithms that can predict glucose level evolution in light of the data collected and the development of models of data analysis suggesting treatment adjustments (www.diaadvisor. eu) prefigure an increase in the benefits of CGM at the cost of fewer constraints.

Another prospect is the integration of CGM in closed-loop systems ("artificial pancreas") capable of automated delivery of insulin according to the glucose level data and their short-term tendency [57]. These models have already proven in a hospital milieu their safety and effectiveness in the prevention of nocturnal hypoglycaemic events in adults [58] and in children and adolescents [59]. Their use outside hospitals and their validation beyond the nocturnal period are already planned (www.apathome.eu).

CGM is thus only at an initial stage of its clinical application but its indications have already been validated and recognized by professional practice committees [49,60,61]. The prospects for its development point to the next stages of CGM, which will call for other recommendations.

\section{Disclosure of interest}

B. Guerci participates in advisory boards and as consultant for clinical study and has received fees for speaking in symposia and substantial contributions to the finances of a company or organisation (Bristol-Myers Squibb, Sanofi Aventis, GlaxoSmithKline, Novartis, Novo Nordisk, Eli lilly, Boehringer Ingelheim, Pfizer, MSD, Roche Diagnostic, Medtronic, Menarini Diagnostic, Abbott, Vitalaire, Dinno Santé).

J.-P. Riveline participates in advisory boards and as a consultant for Abbott Diabetes Care, Lifescan, SanofiAventis and Eli-Lilly, and he has received honoraria, payment for presentations, travel and accommodation expenses from Abbott Diabetes Care, Sanofi-Aventis and Novo-Nordisk.

P.-Y. Benhamou participates in advisory boards or as a consultant for Medtronic, Lifescan, Sanofi-Aventis, Eli-Lilly, and has received fees for speaking in symposia from Abbott, Medtronic, Eli-Lilly, Roche, Novo-Nordisk.

E. Renard participates in advisory boards and as a consultant for Menarini Diagnostics, Abbott, Cellnovo, DexCom Inc, Eli-Lilly, Johnson \& Johnson, Animas, LifeScan, Medtronic, Novartis, Novo-Nordisk, Roche Diagnostics, Sanofi-Aventis, Abbott, DexCom Inc., Insulet Inc.

P. Schaepelynck, L. Meyer, S. Baillot-Rudoni, R.-P. Radermecker, B. Delenne, I. Mantovani, V. Sulmont declare that they have no conflicts of interest concerning this article.

N. Tubiana-Rufi participates in scientific boards for Medtronic and Novo Nordisk.

B. Catargi: FMC (Sanofi, Novartis, BMS, Lilly, Novo); clinical study for Sanofi ; conferences: attendance as audience member (cost of travel and accommodation paid for by an organisation or company) from MSD; boards (Lifescan, Abbott).

A. Sola-Gazagnes: conferences: attendance as contributor and occasional involvements: advisory services for Medtronic, Abbott, Roche Diagnostic.

A. Penfornis: member of boards of AstraZeneca, BristolMyers Squibb, Jansen-Cilag, Merck-Serono, Novartis, Novo Nordisk, and Sanofi Aventis. He has received payment for the development of educational presentations including speakers' office services from Abbott, Eli Lilly, Medtronic, MerckSerono, Merck Sharp \& Dohme, Novartis, Novo Nordisk, and Sanofi Aventis. He has had travel and accommodation expenses covered or reimbursed by Abbott, BoehringerIngelheim Pharmaceutical, Eli Lilly, Merck Sharp \& Dohme, Novartis, Novo Nordisk, Sanofi Aventis.

H. Hanaire participates in advisory boards or as a consultant for Abbott and Medtronic, and has received fees for speaking in symposia from Abbott and Medtronic.

D. Brie-Durain : Roche, Lilly, Abbott, Sanofi.

R. Leroy: conferences: attendance as contributor or occasional involvements: expert reports for Medtronic, Abbott; conferences: attendance as audience member (cost of travel and accommodation paid for by an organization or company) for NOVOLAB; occasional involvements: advisory services for IPS SANTE.

N. Jeandidier: presentations for Lilly, Novo; Member of boards of Novo Nordisk; Participation in scientific boards (Novo, Sanofi-Aventis); Clinical trials: as main (head) clinical or laboratory investigator, or study coordinator (Lilly, Novo Nordisk). 


\section{References}

[1] The Diabetes Control and Complications Trial Research Group. The effect of intensive treatment of diabetes on the development and progression of long-term complications in insulin-dependent diabetes mellitus. The Diabetes Control and Complications Trial Research Group. N Engl J Med 1993;329:977-86.

[2] The Diabetes Control and Complications Trial Research and EDIC Group. Sustained effect of intensive treatment of type 1 diabetes mellitus on development and progression of diabetic nephropathy: the Epidemiology of Diabetes Interventions and Complications (EDIC) study. JAMA 2003;290:2159-67.

[3] The Diabetes Control and Complications Trial Research Gro: Hypoglycemia in the Diabetes Control and Complications Trial. Diabetes 1997;46:271-86.

[4] The Diabetes Control and Complications Trial Research Gro. Influence of intensive diabetes treatment on quality-of-life outcomes in the diabetes control and complications trial. Diabetes Care 1996;19:195-203.

[5] Rapaport R, Sills IN. Implications of the DCCT for children and adolescents with IDDM. N J Med 1994;91:227-8.

[6] Jeandidier N, Riveline JP, Tubiana-Rufi N, Vambergue A, Catargi B, Melki V, et al. Treatment of diabetes mellitus using an external insulin pump in clinical practice. Diabetes Metab 2008;34:425-38.

[7] DAFNE Study Group. Training in flexible, intensive insulin management to enable dietary freedom in people with Type 1 diabetes: dose adjustment for normal eating (DAFNE) randomized controlled trial. Diabet Med 2003;20(Suppl 3):4-5.

[8] Bolli GB, Andreoli AM, Lucidi P. Optimizing the replacement of basal insulin in type 1 diabetes mellitus: no longer an elusive goal in the post-NPH era. Diabetes Technol Ther 2011;13(Suppl 1):S43-52.

[9] Chase HP, Lockspeiser T, Peery B, Shepherd M, MacKenzie T, Anderson J, et al. The impact of the Diabetes Control and Complications Trial and Humalog insulin on glycohemoglobin levels and severe hypoglycemia in type 1 diabetes. Diabetes Care 2001;24:430-4.

[10] Fagot-Campagna A, Fosse SCR. Caractéristiques, risque vasculaire et complications chez les personnes diabétiques en France métropolitaine : d'importantes évolutions entre Entred 2001 et Entred 2007. Bulletin Epidémiologique Hebdomadaire 2009;450-4.

[11] Juvenile Diabetes Research Foundation Continuous Glucose Monitoring Study Group. The Effect of Continuous Glucose Monitoring in WellControlled Type 1 Diabetes. Diabetes Care 2009;32:1378-83.

[12] Cryer PE, Davis SN, Shamoon H. Hypoglycemia in Diabetes. Diabetes Care 2003;26:1902-12.

[13] Smith CB, Choudhary P, Pernet A, Hopkins D, Amiel SA. Hypoglycemia unawareness is associated with reduced adherence to therapeutic decisions in patients with type 1 diabetes. Diabetes Care 2009;32:1196-8.

[14] Juvenile Diabetes Research Foundation Continuous Glucose Monitoring Study Group. Prolonged nocturnal hypoglycemia is common during 12 months of continuous glucose monitoring in children and adults with type 1 diabetes. Diabetes Care 2010;33:1004-8.

[15] Cosson E, Hamo-Tchatchouang E, Dufaitre-Patouraux L, Attali JR, Paries J, Schaepelynck-Belicar P. Multicentre, randomised, controlled study of the impact of continuous sub-cutaneous glucose monitoring (GlucoDay) on glycaemic control in type 1 and type 2 diabetes patients. Diabetes Metab 2009;35:312-8.

[16] Ludvigsson J, Hanas R. Continuous subcutaneous glucose monitoring improved metabolic control in pediatric patients with type 1 diabetes: a controlled crossover study. Pediatrics 2003;111:933-8.

[17] Chico A, Vidal-Rios P, Subira M, Novials A. The continuous glucose monitoring system is useful for detecting unrecognized hypoglycemias in patients with type 1 and type 2 diabetes but is not better than frequent capillary glucose measurements for improving metabolic control. Diabetes Care 2003;26:1153-7.

[18] Tanenberg R, Bode B, Lane W, Levetan C, Mestman J, Harmel $\mathrm{AP}$, T, et al. Use of the Continuous Glucose Monitoring System to guide therapy in patients with insulin-treated diabetes: a randomized controlled trial. Mayo Clin Proc 2004;79:1521-6.

[19] Hirsch IB, Abelseth J, Bode BW, Fischer JS, Kaufman FR, Mastrototaro J, et al. Sensor-augmented insulin pump therapy: results of the first randomized treat-to-target study. Diabetes Technol Ther 2008; $10: 377-83$.

[20] Wolpert HA: The nuts and bolts of achieving end points with real-time continuous glucose monitoring. Diabetes Care 2008;31(Suppl 2):S146-9.

[21] Garg SK, Voelmle MK, Beatson CR, Miller HA, Crew LB, Freson BJ, et al. Use of continuous glucose monitoring in subjects with type 1 diabetes on multiple daily injections versus continuous subcutaneous insulin infusion therapy. Diabetes Care 2011;34:574-9.

[22] Bequette BW. Continuous glucose monitoring: real-time algorithms for calibration, filtering, and alarms. J Diabetes Sci Technol 2010;4:404-18.

[23] Deiss D, Bolinder J, Riveline J-P, Battelino T, Bosi E, TubianaRufi N, et al. Improved glycemic control in poorly controlled patients with type 1 diabetes using real-time continuous glucose monitoring. Diabetes Care 2006;29:2730-2.

[24] Juvenile Diabetes Research Foundation Continuous Glucose Monitoring Study Group. Continuous glucose monitoring and intensive treatment of type 1 diabetes. N Engl J Med 2008;359:1464-76.

[25] Raccah D, Sulmont V, Reznik Y, Guerci B, Renard E, Hanaire H, et al. Incremental value of continuous glucose monitoring when starting pump therapy in patients with poorly controlled type 1 diabetes. Diabetes Care 2009;32:2245-50.

[26] Bergenstal RM, Tamborlane WV, Ahmann A, Buse JB, Dailey G, Davis SN, et al. Effectiveness of sensor-augmented insulin-pump therapy in type 1 diabetes. N Engl J Med 2010;363:311-20.

[27] Pickup JC, Freeman SC, Sutton AJ. Glycaemic control in type 1 diabetes during real time continuous glucose monitoring compared with self monitoring of blood glucose: meta-analysis of randomised controlled trials using individual patient data. BMJ 2011;343:d3805.

[28] Langendam MW, LuijfYM, Hooft L, Devries JH, Mudde AH, Scholten RJ. Continuous glucose monitoring systems for type 1 diabetes mellitus. Cochrane Database Syst Rev 2012;1:CD008101.

[29] Juvenile Diabetes Research Foundation Continuous Glucose Monitoring Study Group. Sustained benefit of continuous glucose monitoring on $\mathrm{A}_{1 \mathrm{c}}$, glucose profiles, and hypoglycemia in adults with type 1 diabetes. Diabetes Care 2009;32:2047-9.

[30] Riveline JP, Schaepelynck P, Chaillous L, Renard E, Sola-Gazagnes A, Penfornis A, et al. Assessment of patient-led or physician-driven continuous glucose monitoring in patients with poorly controlled type 1 diabetes using basal-bolus insulin regimens: A 1-year multicenter study. Diabetes Care 2012;35:965-71.

[31] Bergenstal RM, Tamborlane WV, Ahmann A, Buse JB, Dailey G, Davis $\mathrm{SN}$ J, et al. Sensor-augmented pump therapy for $\mathrm{A}_{1 \mathrm{c}}$ reduction (STAR 3) study: results from the 6-month continuation phase. Diabetes Care 2011;34:2403-5

[32] O'Connell M, Donath S, O'Neal D, Colman P, Ambler G, Jones T, et al. Glycaemic impact of patient-led use of sensor-guided pump therapy in type 1 diabetes: a randomised controlled trial. Diabetologia 2009;52:1250-7.

[33] Jenkins AJ, Krishnamurthy B, Best JD, Cameron FJ, Colman PG, Farish S, et al. Evaluation of an algorithm to guide patients with type 1 diabetes treated with continuous subcutaneous insulin infusion on how to respond to real-time continuous glucose levels. Diabetes Care 2010;33:1242-8.

[34] Hermanides J, Norgaard K, Bruttomesso D, Mathieu C, Frid A, Dayan CM, et al. Sensor-augmented pump therapy lowers $\left.\mathrm{HbA}_{1 \mathrm{c}}\right)$ in suboptimally controlled Type 1 diabetes; a randomized controlled trial. Diabet Med 2011;28:1158-67.

[35] Battelino T, Phillip M, Bratina N, Nimri R, Oskarsson P, Bolinder J. Effect of continuous glucose monitoring on hypoglycemia in type 1 diabetes. Diabetes Care 2011;34:795-800.

[36] Radermecker RP, Saint Remy A, Scheen AJ, Bringer J, Renard E. Continuous glucose monitoring reduces both hypoglycaemia and $\mathrm{HbA}_{1 \mathrm{c}}$ in hypoglycaemia-prone type 1 diabetic patients treated with a portable pump. Diabetes Metab 2010;36:409-13.

[37] Agrawal P, Welsh JB, Kannard B, Askari S, Yang Q, Kaufman FR. Usage and effectiveness of the low glucose suspend feature of the medtronic paradigm veo insulin pump. J Diabetes Sci Technol 2011;5:1137-41.

[38] Choudhary P, Shin J, Wang Y, Evans ML, Hammond PJ, Kerr D, et al. Insulin pump therapy with automated insulin suspension in response 
to hypoglycemia: reduction in nocturnal hypoglycemia in those at greatest risk. Diabetes Care 2011;34:2023-5.

[39] Halford J, Harris C. Determining clinical and psychological benefits and barriers with continuous glucose monitoring therapy. Diabetes Technol Ther 2010;12:201-5.

[40] Rubin RR, Peyrot M. Treatment satisfaction and quality of life for an integrated continuous glucose monitoring/insulin pump system compared to self-monitoring plus an insulin pump. J Diabetes Sci Technol 2009;3:1402-10.

[41] Diabetes Research in Children Network (DirecNet) Study Group: Psychological aspects of continuous glucose monitoring in pediatric type 1 diabetes. Pediatr Diabetes 2006;7:32-8.

[42] Cemeroglu AP, Stone R, Kleis L, Racine MS, Postellon DC, Wood MA. Use of a real-time continuous glucose monitoring system in children and young adults on insulin pump therapy: patients' and caregivers' perception of benefit. Pediatr Diabetes 2010;11:182-7.

[43] Juvenile Diabetes Research Foundation Continuous Glucose Monitoring Study Group: Quality-of-Life Measures in Children and Adults With Type 1 Diabetes. Diabetes Care 2010;33:2175-7.

[44] Yogev Y, Chen R, Ben-Haroush A, Phillip M, Jovanovic L, Hod M. Continuous glucose monitoring for the evaluation of gravid women with type 1 diabetes mellitus. Obstet Gynecol 2003;101:633-8.

[45] Chen R, Yogev Y, Ben-Haroush A, Jovanovic L, Hod M, Phillip M. Continuous glucose monitoring for the evaluation and improved control of gestational diabetes mellitus. J Matern Fetal Neonatal Med 2003; 14:256-60.

[46] Murphy HR, Rayman G, Lewis K, Kelly S, Johal B, Duffield K, et al. Effectiveness of continuous glucose monitoring in pregnant women with diabetes: randomised clinical trial. BMJ 2008:337.

[47] Kordonouri O, Pankowska E, Rami B, Kapellen T, Coutant R, Hartmann R, et al. Sensor-augmented pump therapy from the diagnosis of childhood type 1 diabetes: results of the Paediatric Onset Study (ONSET) after 12 months of treatment. Diabetologia 2010;53:2487-95.

[48] Mauras N, Beck R, Xing D, Ruedy K, Buckingham B, Tansey M, et al. A randomized clinical trial to assess the efficacy and safety of real-time continuous glucose monitoring in the management of type 1 diabetes in young children aged 4 to 10 years. Diabetes Care 2012;35:204-10.

[49] Phillip M, Danne T, Shalitin S, Buckingham B, Laffel L, Tamborlane W, Battelino T. Use of continuous glucose monitoring in children and adolescents. Pediatr Diabetes 2012;13:215-28.
[50] Battelino T, Conget I, Olsen B, Schütz-Fuhrmann I, Hommel L, Hoogma R, et al. Group SS: The SWITCH study: continuous glucose monitoring in type 1 diabetes. Pediatric Diabetes 2011;12 (suppl. 15):30.

[51] Chase HP, Beck RW, Xing D, Tamborlane WV, Coffey J, Fox LA, et al. Continuous glucose monitoring in youth with type 1 diabetes: 12-month follow-up of the Juvenile Diabetes Research Foundation continuous glucose monitoring randomized trial. Diabetes Technol Ther 2010;12:507-15.

[52] Juvenile Diabetes Research Foundation Continuous Glucose Monitoring Study Group. Factors predictive of use and of benefit from continuous glucose monitoring in type 1 diabetes. Diabetes Care 2009;32:1947-53.

[53] McQueen RB, Ellis SL, Campbell JD, Nair KV, Sullivan PW. Costeffectiveness of continuous glucose monitoring and intensive insulin therapy for type 1 diabetes. Cost Eff Resour Alloc 2011;9:13.

[54] Huang ES, O'Grady M, Basu A, Winn A, John P, Lee J, et al. Group Juvenile Diabetes Research Foundation Continuous Glucose Monitoring Study Group: the cost-effectiveness of continuous glucose monitoring in type 1 diabetes. Diabetes Care 2010;33:1269-74.

[55] Group UKPDS. Cost effectiveness analysis of improved blood pressure control in hypertensive patients with type 2 diabetes: UKPDS 40 . BMJ 1998;317:720-6.

[56] DeVries JH. Continuous glucose monitoring: coming of age? Eur J Endocrinol 2012;166:1-4

[57] Cobelli C, Renard E, Kovatchev B. Artificial pancreas: past, present, future. Diabetes 2011;60:2672-82.

[58] Kovatchev B, Cobelli C, Renard E, Anderson S, Breton M, Patek S, et al. Multinational study of subcutaneous model-predictive closed-loop control in type 1 diabetes mellitus: summary of the results. J Diabetes Sci Technol 2010;4:1374-81.

[59] Hovorka R, Allen JM, Elleri D, Chassin LJ, Harris J, Xing D, et al. Manual closed-loop insulin delivery in children and adolescents with type 1 diabetes: a phase 2 randomised crossover trial. Lancet 2010;375:743-51.

[60] Recommendations ADA: Executive summary: standards of medical care in diabetes--2011. Diabetes Care 2011;34(Suppl 1):S4-10.

[61] Blevins TC, Bode BW, Garg SK, Grunberger G, Hirsch IB, Jovanovic L, et al. Statement by the American Association of Clinical Endocrinologists Consensus Panel on continuous glucose monitoring. Endocr Pract 2010;16:730-45.

[62] Hirsch IB: Clinical review: Realistic expectations and practical use of continuous glucose monitoring for the endocrinologist. J Clin Endocrinol Metab 2009;94:2232-8. 


\section{Appendix}

\section{Continuous glucosemonitoring: good clinical practice recommendations and organisational aspects}

The success of CGM depends not only on the selection of patients capable of using it at least $40 \%$ of the time [19,23-26] and of applying the data but equally on the development of a specific educational program administered by an experienced team [19].

\section{Selection of patients}

The evaluation of the patient's knowledge and ability to selfmanage his treatment and of his motivation is a prerequisite. CGM does not dispense with SMBG necessary to calibrate the devices and requires involvement on the part of the patient. The patient must know:

- the concept of intensive insulin therapy, the role of basal and prandial insulin, the duration of their action and the ways of adapting their doses;

- the targeted range of glucose levels that has been proposed to him;

- what to do in case of high and low glucose level;

- the importance of taking into account trends of glucose variations (dynamic notion).

Motivation can be assessed, among other things, by:

- the involvement of the patient in the management of his treatment;

- the frequency of SMBG. Indeed, in the JDRF study, the frequency of SMBG before the study (6 SMBG and more per day) and adherence to the system in the three first weeks following inclusion were factors predictive of adherence to sensor use ( $p<0.001)$, unlike the educational level of patients [52];

- the regularity of the adjustments of insulin doses.

The patient must be motivated to change in case CGM reveals inappropriate behaviour. CGM can necessitate a reorganisation of personal time devoted to the diabetes and must not be perceived as a means of reducing a patient's self-management of his diabetes. However, after learning the patient's expectations and his acceptance of the prerequisites to optimal use of CGM, there is no reason to refuse a trial of CGM to a patient who wants it. Expectations can evolve with time and so a patient motivated to try CGM by $\mathrm{HbA}_{1 \mathrm{c}}$ out of target may become interested in CGM for the management of physical activity or the prevention of hypoglycaemia.

The patient's anxiety over glucose values must be evaluated with the aim of preventing overcorrection of high or low glucose level.

\section{Information about modalities and conditions of use}

The patient must be informed of and accept the conditions and restrictions on use that will permit him to get the most from the system. These include:
- accepting the awkwardness of the device;

- wearing it as often as possible;

- respecting the rules of calibration.

In the current state of the technology, the setup of CGM devices requires good visual acuity.

\section{III.Training the patient in what CGM is}

The patient must assimilate the specificity of CGM.

- the variable measured is not blood glucose but the level of glucose in the subcutaneous tissue;

- the fluctuation of these two variables is parallel but not simultaneous: the time lag is inherent in the physiology;

- the use of CGM data is based on the interpretation of trends and not on the analysis of spot values. Thus it is not necessary constantly to compare the results of CGM with capillary blood glucose measurements except in cases where a malfunction of the system is suspected (see below).

\section{Technical training and education}

The setup of a CGM device and initiation in its use require, on the one hand, technical training and, on the other hand, education in the use of the data; both are indispensable to the optimal management of the data furnished by CGM. More time is necessary for this twofold training - diabetological and technical - in the paediatric population, given the diversity of those involved with the child (parents, teachers, day-care providers, etc.).

\section{IV.1. Facility infrastructure}

The hospital and/or private-practice infrastructure involved in CGM education should have a practice specialised in diabetology and be based ideally on a physician-nurse team trained in diabetes management and comprehensive diabetes education.

Initiation in CGM is facilitated when it is done by a team of health-care professionals experienced in treatment with the external pump [62].

The team should have a regular practice and an advanced knowledge of the use of the CGM device proposed to the patient so it can provide answers adapted to the patient (site and time of insertion, local anaesthesia, calibration schedule, tightness, hygiene, alarm settings, local bleeding, storage condition, attention to expiration, etc.); this exchange is key to the acceptance of CGM.

The training can be given during hospitalisation, in outpatient facilities or in private practice. It can be done individually or in groups [62]. The initial training takes at least two hours for an adult. 


\section{IV.2. Training technique}

It is not recommended that CGM training be done at the same time as initiation in the insulin pump (expert consensus). The technical nature of each of these devices requires, for the majority of patients and their families, a separate period of learning and adaptation, in the current state of the technologies. Nevertheless, in paediatric situations, recent data suggest that use of CGM with a pump from the time the diabetes is diagnosed can be helpful in the prevention of severe hypoglycaemias [47].

Most ways of using CGM devices are similar whatever the device (Table 1).

\section{IV.3. Technical training includes the following steps:}

- Presentation of the three components of the system (sensor, transmitter and receiver), installation of the batteries, presentation of the screen icons (glucose values, trend arrows, graphics, alarm messages, etc.) and their meaning.

- Insertion of the sensor and initialisation of the system.

- Procedures for calibrating the CGM device.

- Technique of setting the alarms.

\section{IV.4. Insertion of the sensor}

The first insertion of the sensor must always be done under supervision and cover the following points:

- attention to rigorous asepsis;

- choice of the site of insertion:

- preference at the outset for easily accessible areas so possible initial local reactions can be watched for;

- avoidance of areas where adipose tissue is over- or underdeveloped, exposed to irritation (posing a risk of disinsertion) or altered (as with scars, stretch marks, etc.).

- checks of the insertion site if the device permits it (Table 1).

At the time of the first insertion, the patient is informed of the practical aspects concerning watertightness in the shower, bath or swimming pool, electromagnetic interference as at airport security checkpoints, contact sports, transmitter/receiver range, etc.

\section{IV.5. Calibration}

The patient is trained to do the number of capillary blood glucose measurements required by the particular CGM device, on a schedule compatible with the requirements of calibration and his own daily routine. For optimal calibration, periods of great glucose variation should be avoided, specifically the early postprandial period. The reliability of the blood glucose meter and the technique of monitoring capillary blood glucose should also be checked. It is nevertheless inadvisable to calibrate too often because of the risk of introducing unstable or irrelevant values. Ideally, the calibration should be done only when no directional trends appear on the screen.

\section{IV.6. System alarms}

These must be distinguished from user alarms (see below), henceforth to be called alerts. The patient must be trained to know how to react to system alarms to reduce the risk of his giving up on the system early. These alarms alert patients to:

- a break in the connection between the sensor and the device;

- the need for calibration;

- the end of the sensor's life.

\section{IV.7. Education and use of CGM}

The use by the patient of the data furnished by CGM is conditioned by the expectations of the patient and the metabolic targets set with the physician, as well as by the nature of the insulin regimen.

A step-by-step initial utilization is suggested:

- the first days (1 to 3 sensors) can be a period of observation and collection of information, particularly for the purpose of interpreting data from nocturnal and postprandial periods;

- in the following days, the treatment can be adjusted and the modifications validated;

- in the subsequent days, the measures taken in the course of physical activity, heavy meals, correction of low blood sugar, etc., can be tested.

The programming and activation of alerts are done on a case-by-case basis. Observation of the data and activation of the alerts are by themselves insufficient. They must be accompanied by recommendations for action.

\section{IV.8. Setting the alerts}

With all the devices, alerts are threshold alarms that warn the patient when the glucose value drops below or rises above selected threshold values. Certain devices offer complementary alerts that refine the use of CGM data:

- in the initial learning phase, to facilitate adaptation to the system and avoid excessive information, it's advisable not to activate the alert functions during the first few days. However, if CGM has been proposed for an express purpose such as the management of hypoglycaemias, the corresponding alerts can have a place from the moment of the first insertion. In all cases when the alerts are activated, the patient should be informed of the possible disagreement of frequent alerts and the way to deactivate them. If one chooses to activate the alerts at the outset, it is preferable to stick to alerts with low and/or high thresholds over a wide range. For example, the following standard thresholds can be proposed for low and high alerts at the time of initiation: low glucose threshold $\leq 60 \mathrm{mg} / \mathrm{dl}$, high glucose threshold $\geq 250$ to $300 \mathrm{mg} / \mathrm{dl}$;

- in the phase of advanced use, the activation of the alerts and their thresholds can be personalised. The patient can choose to adjust his behaviour by using the trend 
indicators. These indicators - an arrow pointing down or up according to the trend of the concentration of interstitial glucose - use 1 or 2 arrows to show visually the rate of speed of the variation of glucose values. Other alerts, depending on the device used, can inform the patient of the imminence of his arrival at a threshold (predictive alerts). For example, predictive alerts are set to begin 10 minutes before the predicted onset of low blood glucose, while rate-of-speed alerts are set to begin at $5 \mathrm{mg} / \mathrm{dl} / \mathrm{min}$;

- the CGM system contained in the Veo ${ }^{\circledR}$ pump (Medtronic) offers a specific function called "low glucose suspend." The diffusion of insulin is interrupted for a period of up to 2 hours as long as the patient does not respond to the programmed low glucose alert. The threshold value "low glucose suspend" can be set between 40 and a higher value chosen by the health-care provider (and the patient).

Here are some suggested actions in the absence, at this time, of validated guidelines:

- observation of a high but stable or rising CGM glucose value, above a personalised threshold, can lead to the administration of a compensatory dose of insulin, with or without confirmation by a prior SMBG. This proceeding must nevertheless be discouraged in certain circumstances, such as before driving or in the case of discordance between the patient's symptoms and the values shown by the CGM device;

- the patient should be advised of the level of the compensatory dose according to the CGM value. The corrective bolus considered can be administered, as usual, according to the patient's sensitivity to insulin. However, CGM permits one to take into account the rate of change of the values and to adjust the corrective doses. For example, the corrective bolus can be increased or decreased by $10 \%$ according as the gradient of the CGM reaches or exceeds $2 \mathrm{mg} / \mathrm{dl} / \mathrm{min}$;

- an interval of about 3 hours must be observed between two compensatory insulin doses. Also, the ineffectiveness of a compensatory dose after three hours should lead the patient to question the adequacy of the dose but also, if the treatment is by pump, to suspect a technical problem with the catheter;

- observation of a low glucose value, a fortiori if the gradient is descending, can, even in the absence of symptoms, lead to corrective or preventive measures for low blood glucose, without the absolute necessity for confirmation by SMBG.

\section{IV.9. Explain to the patient the usual causes of discordance between SMBG and interstitial value}

The patient must be made aware of situations at risk for discordance. These are:

- $\quad$ essentially periods of rapid glycaemic fluctuation - e.g., sharp prandial glycaemic peaks (tied to prandial insulin taken too late or forgotten or taken in an insufficient dose; to an obstructed pump catheter; to correction of low blood glucose; or to dawn phenomenon) - or, contrariwise, sharp glycaemic drops. The situation usually observed is belatedness in the increase or decrease in the CGM value vis-à-vis the $\mathrm{SMBG}$ value;

- also the period at the end of a sensor's life, with the sensor measurements lower than the SMBG.

\section{IV.10. What place is there for self-monitoring of blood glucose?}

Apart from SMBG for calibration, the need for other SMBG measurements must be discussed with the patient on a caseby-case basis, according to the usual therapeutic regimen and the use envisioned for CGM. The actual data do not permit one to recommend that a therapeutic action such as correction of low blood glucose, a corrective insulin bolus, or a change in the basal insulin dose be made conditional on an SMBG to validate the CGM data. However, an SMBG seems useful before a corrective dose is decided on in cases of high glucose value.

At the end of the initial sequence of education, the patient is given:

- written instructions on the use of data provided by the sensor and the need to control low blood glucose;

- a protocol for adjusting insulin doses and snacks.

\section{Follow-up of patients using CGM}

It is important to stay in close contact with patients in the course of initiation and to emphasise the consistencies and strong points of the system in a first follow-up shortly afterwards. The reading of the first graphs enables one to:

- show their consistency with the SMBG;

- show, in addition, that analysis with CGM yields knowledge of the grey areas not analysed by intermittent measurement, such as the nocturnal and postprandial periods;

- elaborate objectives for the use of the sensor, such as analysis of the problems of low or high glucose level and analysis of specific periods of the day or night.

\section{V.1. Frequency of follow-up: set a date for early evaluation}

How this evaluation will be done will be determined with the patient and will depend on whether or not he has the means of downloading the results. The use of data-analysis software is indispensable at this stage. Early evaluation can require at least 45 to 60 minutes. The following schedule for evaluation is proposed:

- a first consultation 7 days after initiation with a trained health-care provider (an RN or physician) to:

- verify the patient's adaptation to the system, including calibrations, sensor replacement, alarms and alerts;

- analyse the first glucose data and the first corrective actions, such as correction of low-blood glucose and supplementary insulin injections;

- review the programming and setting of alarms and alerts; 
- two follow-up consultations with the initiating physician, one four weeks and the other three months after initiation. In addition to checking the items from V1, during these consultations the physician will be able to determine if CGM should continue or not;

- between-visit phone calls. These can be proposed to patients by a trained health-care provider (an RN or physician), above all in the phase following the insertion of a sensor - for example, on day 3 or day 4 after the insertion, at two weeks after the initiation, etc.;

- during the first year, a consultation every three months is typically the rule (every $\mathbf{2 - 3}$ months in paediatrics). Subsequent consultations are adapted to the clinical results and the patient's convenience, but there should be no more than 1 year between two consultations. An annual re-evaluation will allow the physician to determine if CGM use should be renewed.

\section{V.2. Downloading of data}

Before the consultation, the data can be downloaded by the medical team, the service provider for patients on the pump, or the patient himself from a secure Internet site. It is also possible to access the data directly on a computer during the consultation.

\section{V.3. Criteria for the continuance or suspension of CGM}

These criteria must always be evaluated in a comprehensive educational approach and are not mutually exclusive.
Moreover, the suspension of CGM use on the advice of a physician or at the patient's request does not contraindicate a later attempt, after a certain delay, if the patient's motivation and medical situation justify it.

CGM can be used continuously or during limited but repeated periods over time, as for example with people exercising or doing sports, operating-room nurses, truck drivers and others engaged in at-risk professional activities:

- criteria for the continued use of CGM are:

- adherence of the patient to the technique;

- attainment of the initial objectives of CGM use, from the point of view of the physician and the patient;

- sufficient use of CGM and regular observation in real time of the results (JDRF, Real Trend, Star III);

- at three months, evaluation of the clinical benefit (in terms of time spent above or below fixed glucose targets, severe hypoglycaemia events or ketosis) and/ or of the biological benefit $\left(\mathrm{HbA}_{1 \mathrm{c}}\right)$;

- criteria for the suspension of CGM are:

- in the short term (up to 3 months):

- the patient's request,

- poor physical or psychological tolerance of the device,

- inattention to the calibration instructions and insufficient sensor use in relation to the objective,

- neglect of the schedule of follow-up consultations,

- neglect of the device;

_ in the long term (at 3 months or more) the same criteria as above with in addition:

- nonattainment of the initial objective of CGM use, - degradation of glucose control or quality of life. 